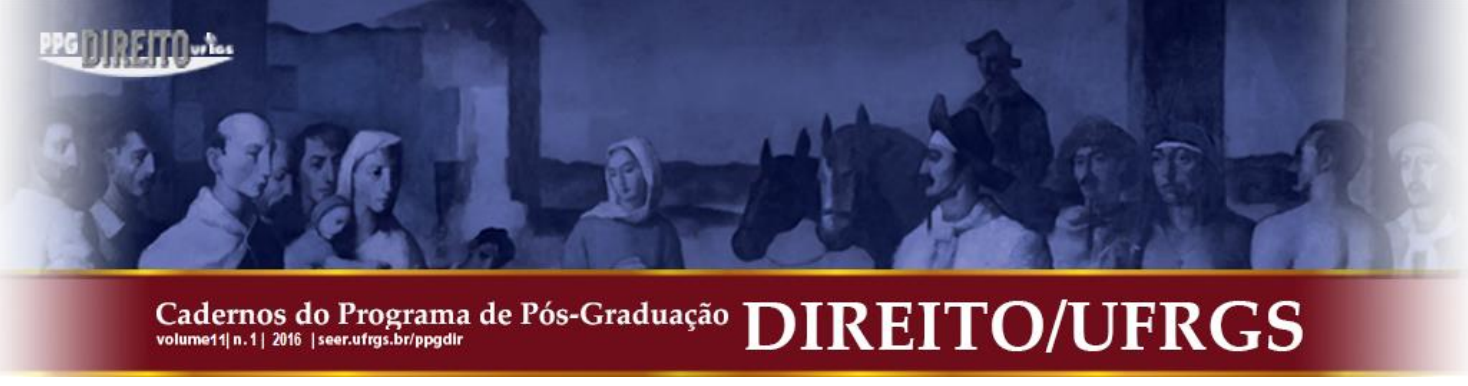

\title{
A LICITUDE DOS SERVIÇOS DE TRANSPORTE PRESTADOS PELO APLICATIVO UBER
}

\author{
THE LAWFULNESS OF TRANSPORT SERVICES PROVIDED BY UBER APP
}

\author{
Cláudia Mara de Almeida Viegas* \\ Luís Henrique Vasconcelos da Silva Letra**
}

\begin{abstract}
RESUMO: O presente trabalho tem por objetivo analisar a legalidade dos serviços de transporte contratados através do aplicativo UBER, pelo qual são conectados motoristas autônomos e pessoas em busca de transporte de passageiros. Pretende-se, no primeiro momento, investigar e conceituar o mecanismo que envolve o aplicativo, analisando os aspectos juridicamente relevantes ao sistema de contratação do serviço. Em seguida, pelo método dedutivo, verifica-se o enquadramento da prestação de serviço em questão como um negócio jurídico - contrato de transporte de pessoas -, preconizado pelos arts. 734 e seguintes do Código Civil. Posteriormente, investiga-se o transporte público de pessoas, com análise normativa federal e exemplos de normas municipais editadas em Belo Horizonte, São Paulo e Rio de Janeiro, que objetivaram restringir as atividades prestadas pelo UBER. Por fim, pelo método indutivo, faz-se a análise jurisprudencial de casos pontuais impugnando a legislação municipal citada, a fim de expor os argumentos jurídicos favoráveis e contrários à licitude do sistema de transporte privado titularizado como UBER no aspecto da prática jurídica.
\end{abstract}

PALAVRAS-CHAVE: UBER. Contrato de transporte de pessoas. Transporte público. Transporte Privado.

\begin{abstract}
This paper aims to examine the legality of the transport services contracted by UBER app, through which selfemployed drivers and people searching transport are connected. It was intended, at first, to investigate and conceptualize the mechanism that involves the app, analyzing important legal aspects of the hiring of the service. Then, through deductive reasoning, it was verified the framework of this service as a legal business passenger transport contract - expressed in the article 734 and the following articles of the Brazilian Civil Code. Later, the public transport of passengers was investigated, with the analysis of federal norms and examples of municipal rules issued in Belo Horizonte, São Paulo and Rio de Janeiro, which aimed to restrict the services provided by UBER. Finally, through inductive reasoning, case law analysis of individual cases challenging the cited municipal legislation were investigated, in order to expose legal arguments in favor and against the legality of the private transport system provided by UBER.
\end{abstract}

KEYWORDS: UBER. Passenger transport contract. Public transport. Private Transport.

SUMÁRIO: Introdução. $1 \mathrm{O}$ contrato de transporte de pessoas. $2 \mathrm{O}$ transporte público de pessoas. 3 Análise jurisprudencial. Conclusão. Referências.

\section{INTRODUÇÃO}

O UBER é um aplicativo de celular criado em março de 2009, no Vale do Silício, nos Estados Unidos, o qual tem por função primordial disponibilizar motoristas particulares a clientes interessados em contratar o serviço de transporte em automóvel. Pelo uso do

\footnotetext{
* Professora dos cursos de Direito da Pontifícia Universidade de Minas Gerais (PUC-Minas) e das Faculdades Del Rey (UNIESP). Doutoranda e Mestre em Direito Privado pela Pontifícia Universidade Católica de Minas Gerais (PUC-Minas). Especialista em Direito Processual Civil pela Universidade Gama Filho. Especialista em Educação à distância pela Pontifícia Universidade de Minas Gerais (PUC-Minas). Especialista em Direito Público - Ciências Criminais pelo Complexo Educacional Damásio de Jesus. Bacharel em Administração de Empresas e Direito pela Fundação Mineira de Educação e Cultura (FUMEC). Tutora do Conselho Nacional de Justiça (CNJ). Servidora Pública Federal do Tribunal Regional do Trabalho, Minas Gerais.

** Especialista em Direito Empresarial pelo Instituto de Educação Continuada (IEC) da Pontifícia Universidade Católica de Minas Gerais (PUC-Minas). Graduado em Direito pela Fundação Mineira de Educação e Cultura (FUMEC).
} 


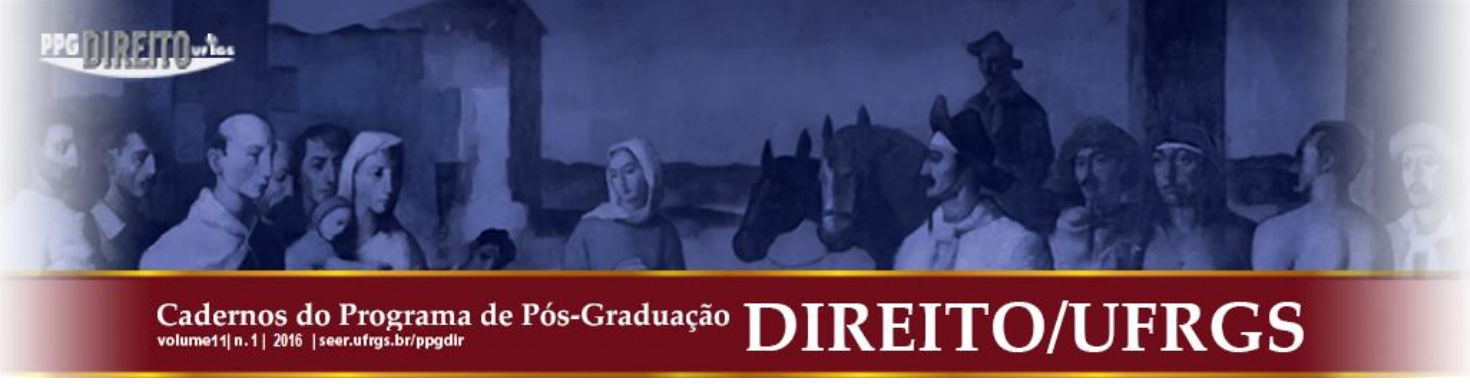

aplicativo, a empresa proprietária da ferramenta, UBER USA, LLC (limited liability company), cobra $20 \%$ (vinte por cento) do valor que o motorista recebe do cliente pela corrida ${ }^{1}$.

Os motoristas são empreendedores individuais, que utilizam a plataforma UBER em sistema de "economia compartilhada" (sharing economy), o qual otimiza o acesso e contato entre passageiros e condutores.

Não há como negar que é da natureza humana compartilhar bens e serviços, as pessoas, em algum momento da sua vida, já emprestou livros, CDs, carro, bicicleta, DVDs, etc. Entretanto, tal comportamento individual de compartilhar coisas até então não tinha o condão de alterar a economia, em passado recente. Faltava escala e as transações se restringiam a amigos, vizinhos e familiares.

Todavia, a partir da difusão da internet no mundo, tal contexto sofreu alterações significativas nas últimas décadas. Inicialmente, a rede mundial de computadores não alterou significativamente o hábito dos consumidores e sua cultura de empréstimo.

Inicialmente, poucos se arriscavam a realizar transações por intermédio dessa plataforma e apenas um grupo pequeno de pessoas conseguia vislumbrar formas de ganhar dinheiro com ela. No entanto, a rápida evolução tecnológica possibilitou o meio legítimo de compartilhamento que culminou no surgimento de aplicativos como o Uber - atualmente bastante popular.

O UBER credencia motoristas profissionais, cujas carteiras de habilitação autorizam o exercício de atividade remunerada de condutor de veículos. A manutenção do cadastramento dos motoristas parceiros, por sua vez, depende das avaliações anônimas que estes recebem dos respectivos passageiros ao término de cada viagem, por meio de um sistema de pontuação. A avaliação varia de zero a cinco estrelas e os motoristas que obtêm média inferior a 4,6 estrelas ficam sujeitos ao descredenciamento pelo UBER

O serviço, atualmente, está disponibilizado em 67 (sessenta e sete) países, em diferentes modalidades de transporte, $\mathrm{v}$ ariando com o tipo de carro disponibilizado ${ }^{2}$.

\footnotetext{
${ }^{1}$ CARDOSO, Ana Luíza. UBER, o aplicativo que enfurece os motoristas: o serviço para chamar motoristas particulares no mundo chega ao Brasil. Revista Época. Editora Globo. publicado em 22 de Julho de 2014. Disponível em: <http://epoca.globo.com/vida/vida-util/tecnologia/noticia/2014/07/buber-o-aplicativob-queenfurece-os-taxistas.htmlac >. Acesso em: 30 dez. 2015.

${ }^{2}$ Informação que consta no site da empresa UBER, disponível em: < https://www.uber.com/pt/cities> e $<$ https://www.uber.com/legal/usa/terms $>$. Acesso em: 30 dez. 2015.
} 


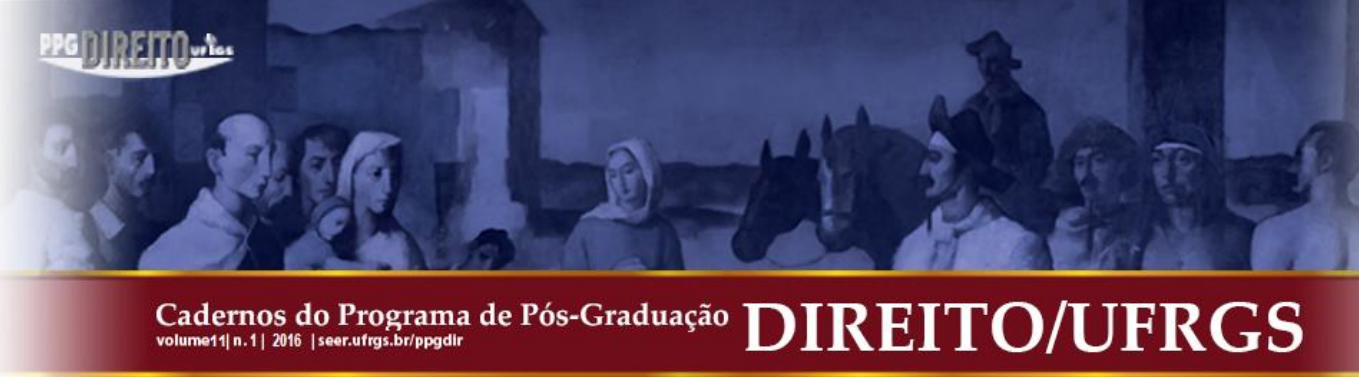

No Brasil, sabe-se da existência do serviço em duas modalidades: o UberBLACK (transporte que utiliza sedans na cor preta), e o UberX (transporte que utiliza carros de menor categoria, sem padronização das cores do veículo), este último com tarifa menor.

O valor das viagens é computado com base na distância a ser percorrida e tempo de viagem, sendo as informações repassadas previamente a cada cliente. O UBER fornece uma estimativa prévia do preço ao passageiro e os pagamentos são realizados por meio de cartão de crédito, por meio do próprio aplicativo.

A simplicidade, a comodidade, a segurança e a eficiência do aplicativo levaram que os serviços prestados através do UBER caíssem no gosto dos usuários.

Todavia, muito em razão desse sucesso, as atividades do UBER vêm sofrendo contestações judiciais e extrajudiciais provenientes, sobretudo, de pessoas, entidades ou forças políticas ligadas aos taxistas e aos proprietários de frotas de táxi.

Uma justificativa é que o serviço ofertado pelo UBER, aparentemente, concorreria e prejudicaria os serviços oferecidos pelos taxistas (motoristas e carros autorizados e credenciados pelo Estado para prestar os serviços de transporte individual de passageiros), o que teria resultado na diminuição da procura de taxis em diversos países.

Outro argumento dos opositores ao aplicativo é que as referidas atividades seriam ilegais, por serem voltadas à prestação de um serviço de transporte público individual de passageiros, que, além de dependente de autorização municipal, seria legalmente monopolizado pelos taxistas.

Seguindo tal perspectiva, os motoristas parceiros da UBER têm sido acusados de prestadores de serviço de "táxi clandestino", por não seguirem a legislação disciplinadora da atividade dos taxistas, e, por isso, praticariam uma pretensa concorrência desleal, prejudicando também os consumidores.

Portanto, várias são as ocorrências de brigas entre taxistas e motoristas do UBER e como tentativa de solucionar o conflito, diversos Municípios buscam regulamentar o serviço dentro de seu território, por legislação municipal, proibindo ou restringindo o exercício da atividade de motoristas de UBER. Em resposta, diversas decisões judiciais são prolatadas, versando sobre a legalidade dos serviços de transporte contratados via UBER no Brasil.

Diante desse contexto, é com a finalidade de contribuir para a paz social que o presente artigo, por meio de técnica bibliográfica e jurisprudencial, pretende demonstrar a legalidade 
taxista e passageiro, que em essência é um negócio jurídico coligado ${ }^{8}$ ao ato administrativo que concede (permite ou autoriza) o exercício do serviço público de táxi pelo motorista.

Neste caso, e aplicando as lições de José Abreu Filho ao exemplo dos táxis, constata-se que o serviço de táxis se dá por um negócio jurídico complexo ${ }^{9}$, constituído pelo ato administrativo de permissão, cessão ou concessão, que é coligado ao contrato entre transportador e passageiro, sendo que aquele torna válido (regular) este. É através dos negócios e declarações convergentes e homogêneas que se forma o negócio jurídico que sustenta o serviço de táxis, serviço de transporte individual de caráter público.

Não restam dúvidas acerca da licitude do contrato de transporte de pessoas celebrado entre particulares, vez que prescrito no Código Civil. Ainda que fosse um contrato atípico (sem previsão e regulamentação legal), seria lícito dada a inexistência de vedação legal, conforme assegura o art. $5^{\circ}$, II, da Constituição Federal: "ninguém será obrigado a fazer ou deixar de fazer alguma coisa senão em virtude de lei" ${ }^{\prime \prime}$.

Ademais, o direito ao livre exercício da atividade de motorista particular é, também, uma garantia constitucional prevista no art. $5^{\circ}$, XIII "é livre o exercício de qualquer trabalho, ofício ou profissão, atendidas as qualificações profissionais que a lei estabelecer" e art. 170, parágrafo único: "É assegurado a todos o livre exercício de qualquer atividade econômica, independentemente de autorização de órgãos públicos, salvo nos casos previstos em lei"l11.

Entretanto, no presente caso, para se analisar com a melhor técnica jurídica sobre a legalidade dos serviços de transporte de pessoas ofertados pelo sistema UBER, não basta apenas aferir a constitucionalidade e legalidade do contrato de transporte privado de pessoas. Faz-se necessário, uma breve análise dos serviços de transporte público de pessoas, o que se dará no próximo tópico.

\footnotetext{
${ }^{8}$ ABREU FILHO, José. O negócio jurídico e sua teoria geral. 5. ed. São Paulo: Saraiva, 2003, p. 99 (Conceito de negócio jurídico coligado).

${ }^{9}$ ABREU FILHO, José. op. cit., p. 99.

10 BRASIL. Constituição da República Federativa do Brasil de 1988. Disponível em: $<$ http://www.planalto.gov.br/ccivil_03/Constituicao/Constituicao.htm> Acesso em: 30 dez. 2015.

11 BRASIL. Constituição $\overline{d a}$ República Federativa do Brasil de 1988. Disponível em: $<$ http://www.planalto.gov.br/ccivil_03/Constituicao/Constituicao.htm> Acesso em: 30 dez. 2015.
} 


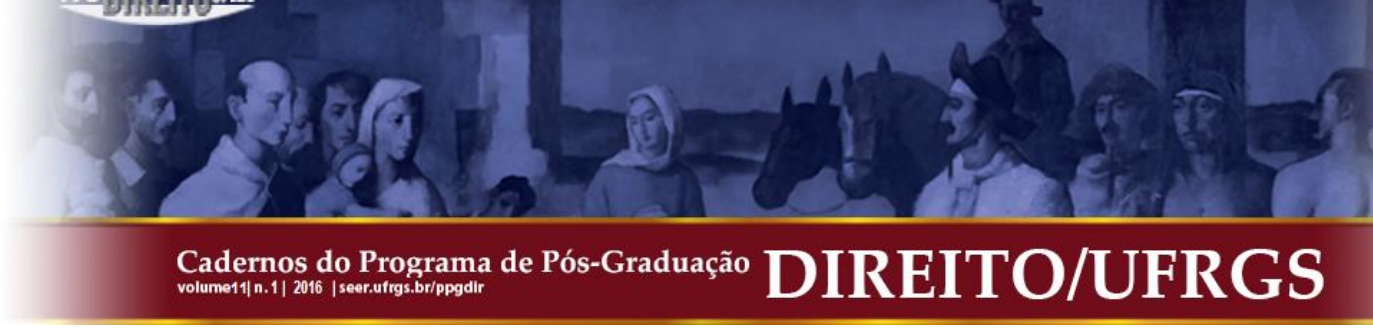

\section{O TRANSPORTE PÚBLICO DE PESSOAS}

Conforme já exposto, grande parte da polêmica sobre o UBER se dá por sua suposta invasão à esfera dos serviços de transporte público individual de pessoas. Sendo assim, é de suma importância descrever aspectos legais relevantes da modalidade pública de transportes.

A competência do Estado, mais especificadamente do Município, para regulamentar os serviços de transporte público urbano, está prevista no art. 30, V, da Constituição da República:

Art. 30. Compete aos Municípios:

V - organizar e prestar, diretamente ou sob regime de concessão ou permissão, os serviços públicos de interesse local, incluído o de transporte coletivo, que tem caráter essencial $^{12}$.

Dentre os temas de interesse local, há os serviços de transporte público individual (táxis), que já foi brevemente analisado no aspecto contratual. Conquanto a competência exclusiva do Município sobre o tema, os táxis foram conceituados por Lei Federal que versa sobre a atividade de taxista, Lei n. 12.468/2011. De acordo com a referida norma, a utilização de veículo para transporte público individual remunerado de passageiros é privativa de taxistas:

Art. $1^{0}$. Fica reconhecida, em todo o território nacional, a profissão de taxista, observados os preceitos desta Lei.

Art. $2^{0}$. É atividade privativa dos profissionais taxistas a utilização de veículo automotor, próprio ou de terceiros, para o transporte público individual remunerado de passageiros, cuja capacidade será de, no máximo, 7 (sete) passageiros ${ }^{13}$.

A Lei impôs condições mínimas ao taxista, tal como o dever de atender o cliente com presteza e polidez, usar trajes adequados, manter o veículo em boas condições de funcionamento e higiene, manter a documentação regular, e observar o Código Nacional de Trânsito (art. $5^{\circ}$ ).

O texto original da Lei, enviado para sanção do Presidente da República na época, regulamentava, de fato, os serviços de táxis, como o ato de cessão do táxi (autorização), possibilidade de locação do veículo e outros, entretanto, tais disposições foram objeto de veto

12 BRASIL. Constituição da República Federativa do Brasil de 1988. Disponível em: $<$ http://www.planalto.gov.br/ccivil_03/Constituicao/Constituicao.htm> Acesso em: 30 dez. 2015.

${ }^{13}$ BRASIL. Lei 12.468, de 26 de Janeiro de 2011. Regulamenta a Profissão de taxista e dá outras providências. Disponível em: <http://www.planalto.gov.br/ccivil_03/_Ato2011-2014/2011/Lei/L12468.htm> Acesso em: 30 dez. 2015. 


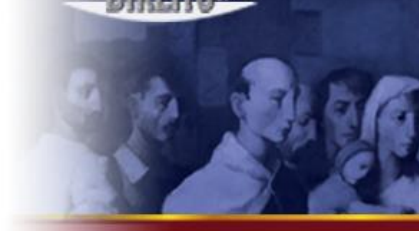

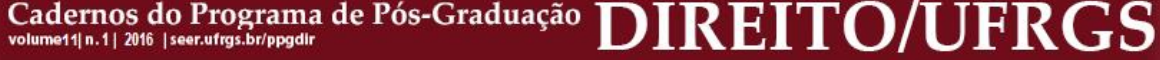

presidencial. Em suas razões, a Presidência justificou que tal regulamentação invade a competência dos Municípios em regulamentar o serviço.

No entanto, outra norma federal foi promulgada para conceituar o serviço de táxi, a Lei n. 12.587 de Janeiro de 2012, que aborda a política de mobilidade urbana. Conceituando os "táxis" no inciso VII do artigo $4^{\circ}$, tem-se que:

Art. $4^{0}$. Para os fins desta Lei, considera-se:

VIII - transporte público individual: serviço remunerado de transporte de passageiros aberto ao público, por intermédio de veículos de aluguel, para a realização de viagens individualizadas ${ }^{14}$.

Dessa forma, tem-se que, pela Lei, o transporte público individual é, necessariamente, aberto ao público. No caso dos veículos do sistema UBER, não se verifica a ampla abertura ao público, vez que é se exige um cadastro prévio do passageiro para que este possa contratar um motorista. Os serviços oferecidos por motoristas no sistema UBER é o de transporte motorizado privado, de acordo com o inciso X, do artigo $4^{\circ}$ da mesma Lei:

$\mathrm{X}$ - transporte motorizado privado: meio motorizado de transporte de passageiros utilizado para a realização de viagens individualizadas por intermédio de veículos particulares $^{15}$.

Sabe-se que os táxis possuem três seguimentos de mercado: (I) os pontos de táxi; (II) os táxis de rua e (III) o porta-a-porta ${ }^{16}$, este último que contempla os serviços de chamada a domicílio, seja por telefone ou aplicativos de celular, tal como o UBER. Entretanto, apenas os dois primeiros seguimentos é que se mostram públicos, em ambiente público e com acesso verdadeiramente universal (não dependendo de um smartphone para acesso).

Os dois seguimentos efetivamente públicos continuam sendo de uso privativo dos serviços de táxi. O primeiro seguimento (pontos de táxi) é privativo dos táxis, viabilizado apenas pela ação dos Municípios na criação e regulamentação do uso desses pontos, situados em vias públicas. O segundo seguimento (de rua), pela própria essência da plataforma UBER,

\footnotetext{
${ }^{14}$ BRASIL. Lei 12.587, de 3 de Janeiro de 2012. Institui a política nacional de mobilidade urbana. Disponível em: < http://www.planalto.gov.br/ccivil_03/_ato2011-2014/2012/lei/112587.htm> Acesso em: 30 dez. 2015.

${ }^{15}$ BRASIL. Lei 12.587, de 3 de Janeiro de 2012. Institui a política nacional de mobilidade urbana. Disponível em: < http://www.planalto.gov.br/ccivil_03/_ato2011-2014/2012/lei/112587.htm>. Acesso em: 30 dez. 2015.

${ }^{16}$ ESTEVES, Luiz Alberto. O Mercado de Transporte Individual de Passageiros: Regulação, Externalidades e Equilíbrio Urbano. Departamento de Estudos Econômicos (DEE) do Conselho Administrativo de Defesa Econômica $\quad$ (CADE), $\quad$ p. $20 . \quad$ Disponível $<$ http://www.cade.gov.br/upload/O\%20Mercado\%20de\%20Transporte\%20Individual\%20de\%20Passageiros.pdf >. Acesso em: 30 dez. 2015.
} 


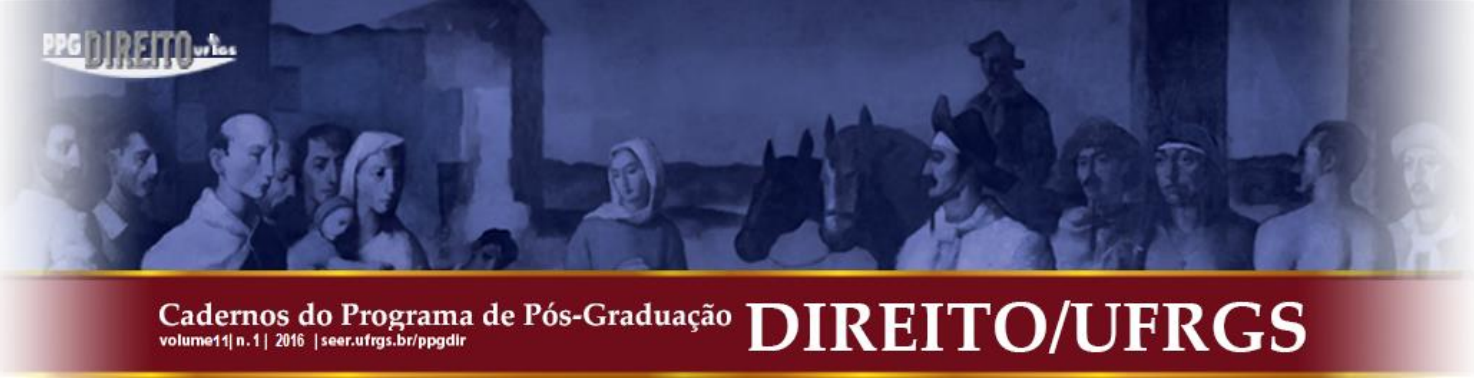

não é utilizado por seus motoristas, dada a ausência de identificação e padronização dos veículos ${ }^{17}$.

Em sendo assim, à luz da conceituação elaborada pela União, por meio da Lei n. 12.587 de Janeiro de 2012, os serviços de transporte ofertados pelo UBER não se caracterizam transporte público individual, dada a inexistência de acesso público (em vias públicas, seja pela rua ou pontos de táxi).

Importa frisar, ainda, que os arts. 12 e 12-A da Lei $n^{0}$ 12.587/2012 evidenciam que o serviço de táxi se configura em serviço de utilidade pública e não um serviço público propriamente dito, que são institutos diversos.

Celso Antônio Bandeira de Mello corrobora a ideia de que não há serviço público prestado pelos táxis, mas sim serviço de utilidade pública, inserido no âmbito da iniciativa privada:

(...) os serviços prestados pelos táxis - e quanto a isto nada importa que o sejam por autônomos ou por empresas - possuem especial relevo para toda a coletividade, tal como se passa, aliás, com inúmeras outras atividades privadas, devendo por isso ser objeto de regulamentação pelo Poder Público, como de fato ocorre, mas obviamente isto não significa que sejam categorizáveis como serviços públicos.

(...) Nem a Constituição, nem a Lei Orgânica dos Municípios, nem a lei municipal regente da matéria qualificam os serviços de táxi como serviços públicos. Contudo, a Constituição foi expressa em qualificar como serviço público o serviço municipal de transporte coletivo local de passageiros (art. 30, V), não se podendo, como é óbvio, considerar casual a explícita menção a 'coletivo'. Nisso, a toda evidência, ficou implícito, mas transparente, o propósito de excluir o transporte individual de passageiros da categorização de serviço público ${ }^{18}$.

Os serviços prestados pelos taxistas não preenchem os critérios relevantes para a caracterização do serviço público, quais sejam: o regime jurídico e a natureza da atividade.

Quanto ao regime jurídico, não há prévia licitação, seguida de concessão ou permissão aos taxistas, como impõe a Constituição da República para os serviços públicos (art. 175, $\mathrm{CR} / 88)$.

Além disso, o título autorizador do exercício da atividade pode ser alienado ou transmitido causa mortis (art. 12-A, $\S \S 1^{\circ}$ e $2^{\circ}$ da Lei $n^{\circ} 12.587 / 2012$ ), circunstância absolutamente inconciliável com os ditames do serviço público.

\footnotetext{
${ }^{17}$ Relembrando que nem mesmo a cor dos veículos é padronizada no serviço denominado “UberX”, conforme já exposto no primeiro tópico.

${ }^{18}$ MELLO, Celso Antônio Bandeira de. Serviços Públicos e Serviço de Utilidade Pública - Caracterização dos Serviços de Táxi - Ausência de Precariedade na Titulação para prestá-los - Desvio de Poder Legislativo. Pareceres de Direito Administrativo. São Paulo: Malheiro, 2011, p. 216-217.
} 


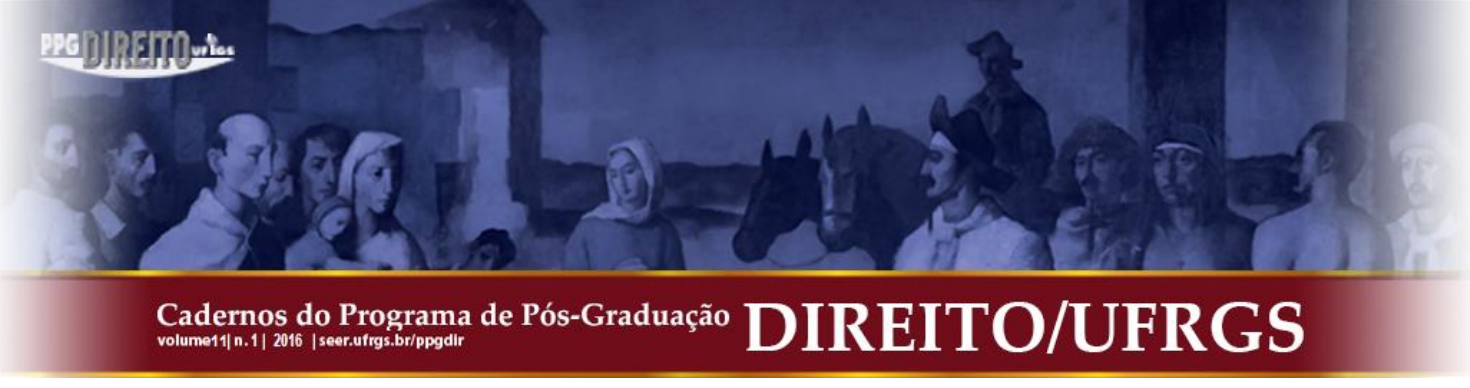

Não bastasse isso, deve ser levado a efeito que o taxista não é obrigado a assegurar a continuidade dos serviços, como ocorre no serviço público.

Verifica-se, portanto, que o transporte individual de passageiros se divide em duas modalidades: a "pública", configura-se em serviço de utilidade pública, prestada de modo privativo pelos táxis, sujeitando-se a regulação estatal; e, a "privada", prevista em lei, ainda não regulamentada, contudo, pelo princípio da livre empresa (art. 170, parágrafo único) não impede a sua prestação pelos particulares interessados em fazê-lo.

Como se observa, não há impedimento para o exercício da atividade de transporte privado na modalidade UBER. Aliás, obstar o transporte individual de passageiros privado violaria gravemente os princípios da livre iniciativa (art. $1^{\circ}$, IV e 170, caput, CR/88), e da livre concorrência (art. 170, IV, CR/88).

A livre iniciativa se relaciona com a liberdade profissional, garantida no art. $5^{\circ}$, inciso XIII, da CR/88, envolvendo tanto a liberdade de iniciar uma atividade econômica, como de organizá-la, geri-la e conduzi-la, estando intimamente ligada à valorização do trabalho humano, fundamentos da ordem econômica nacional (art. 170, caput, da CR/88).

Relacionado à livre iniciativa, o princípio da liberdade de concorrência, previsto no art. 170, inciso IV, da CR/88, garante a proteção da livre competição entre os agentes econômicos no mercado, em prol do consumidor, da eficiência econômica e de outros objetivos socialmente importantes. Paula Forgioni ${ }^{19}$ aduz que a livre concorrência consiste na "garantia da disputa" no campo econômico.

Eros Roberto Grau afirma que:

O princípio da livre concorrência tem uma dupla face. Por um lado, ele limita o Estado, que não pode instituir restrições excessivas que impeçam os agentes econômicos de ingressar, atuar e competir livremente no mercado. Por outro, o princípio impõe que o Poder Público atue sobre o mercado, para proteger a sua higidez, prevenindo e coibindo abusos do poder econômico e práticas anticoncorrenciais, como a formação de monopólios, oligopólios, cartéis etc. É que o princípio não pressupõe, romanticamente, a existência de um mercado atomizado, formado por agentes econômicos de igual poder, competindo em condições equânimes pela preferência do consumidor. Pelo contrário, diante da constatação de que, quando livre de todas as amarras, o poder econômico tende a se concentrar patologicamente em detrimento da concorrência, o princípio impõe a atuação comissiva do Estado, em favor da saúde do próprio mercado ${ }^{20}$.

\footnotetext{
${ }^{19}$ FORGIONI, Paula. Princípios constitucionais econômicos e princípios constitucionais sociais. A formatação jurídica do mercado brasileiro. Revista do Advogado. n. 117, 2012, p. 167.

${ }^{20}$ GRAU, Eros Roberto. A Ordem Econômica na Constituição de 1988 (interpretação e crítica). p. 205-210. Cadernos do Programa de Pós-Graduação em Direito PPGDir./UFRGS | Edição Digital | Porto Alegre | Volume XI | Número 1 | 2016 | P.144-169
} 


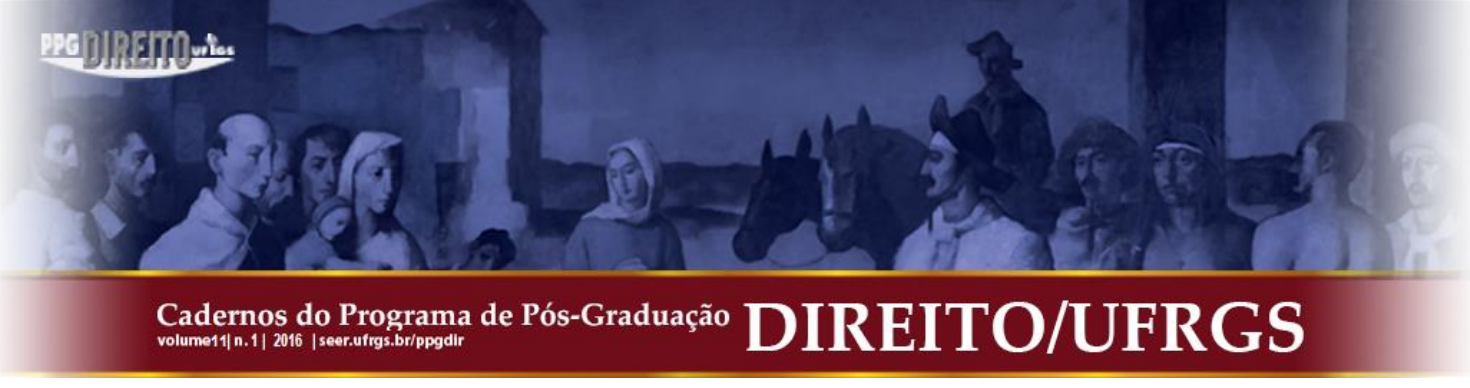

Vê-se, pois, que a instituição de reservas e privilégios aos taxistas e embaraços à competição viola os interesses dos consumidores e de toda a sociedade.

Outro ponto a ser observado é que, no âmbito do transporte privado individual, impera a autonomia privada do motorista do UBER, que tem o direito de aceitar e firmar o contrato com o consumidor de acordo com sua conveniência.

A prestação de serviços do UBER enquadra-se, perfeitamente, no contrato de transporte de pessoas, previsto no Código Civil Brasileiro, pela qual uma das partes, o transportador, ou condutor, se obriga a deslocar de um lugar para outro, a outra parte (passageiro).

Entretanto, alheios à conceituação dada pela referida norma federal, alguns Municípios elaboraram normas sobre o tema.

Em São Paulo, pela Lei n. 16.279 de 8 de Outubro de 2015, o Município buscou proibir os serviços de transporte de pessoas pelo UBER:

Art. $1^{\circ}$ Fica proibido no âmbito da Cidade de São Paulo o transporte remunerado de pessoas em veículos particulares cadastrados através de aplicativos para locais préestabelecidos.

Art. $2^{\circ}$ Para efeitos desta lei, fica também proibida a associação entre empresas administradoras desses aplicativos e estabelecimentos comerciais para o transporte remunerado de passageiros em veículos que não atendam às exigências da Lei $\mathrm{n}^{\mathrm{o}}$ 7.329, de 11 de julho de 1969, que estabelece normas para execução do serviço na Cidade de São Paulo ${ }^{21}$.

Antes da referida norma, a citada Lei Municipal n. 7.329, de 1969 não versava sobre o tema, e limitava a estabelecer que o transporte individual de passageiros por veículos alugados e com taxímetro seria executado mediante prévia outorga de Termo de Permissão e Alvará de Estacionamento.

No Rio de Janeiro, o Município buscou vedar o exercício da atividade de transporte de passageiros pelo sistema UBER através da Lei Complementar Municipal n. 159, de 29 de Setembro de 2015:

Art. 22 A atividade de carona solidária organizada por aplicação móbile é livre, entretanto, sujeita a prévio cadastramento e controle das informações, sendo de interesse público local, vedada sua operação, a título oneroso, como atividade

\footnotetext{
${ }^{21}$ SÃO PAULO. Lei 16.279, de 08 de Outubro de 2015. Dispõe sobre a proibição do uso de carros particulares cadastrados em aplicativos para o transporte remunerado individual de pessoas no Município de São Paulo e dá outras providências. Disponível em: $<$ https://leismunicipais.com.br/a/sp/s/sao-paulo/leiordinaria/2015/1627/16279/lei-ordinaria-n-16279-2015-dispoe-sobre-a-proibicao-do-uso-de-carros-particularescadastrados-em-aplicativos-para-o-transporte-remunerado-individual-de-pessoas-no-municipio-de-sao-paulo-eda-outras-providencias> Acesso em: 30 dez. 2015.
} 


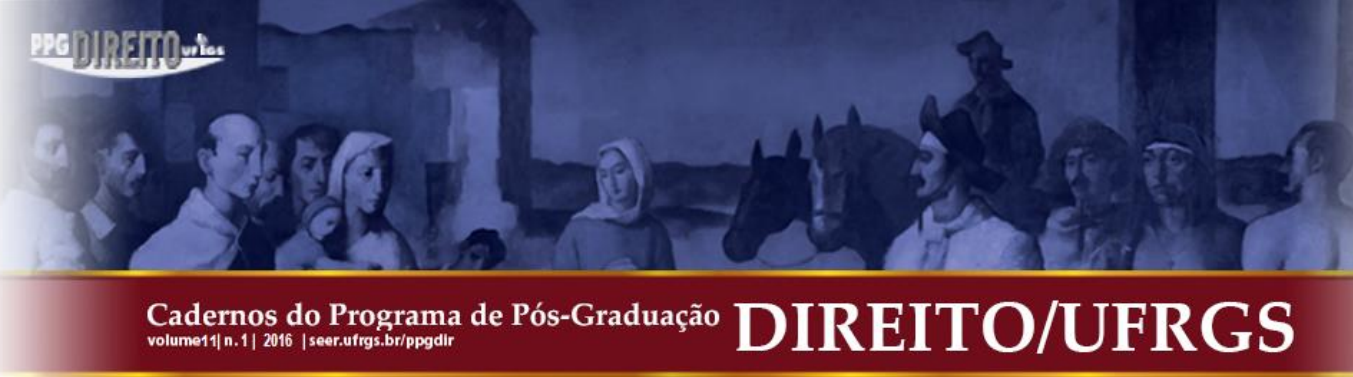

econômica ou profissional, salvo se autorizada pelo Poder Público local e realizada com a observância das seguintes condições:

I - realização de apenas dois deslocamentos em regime de carona solidária, por veículo por dia;

II - possibilidade de compartilhamento de custos, vedada, porém, a cobrança via cartão de crédito ou qualquer meio eletrônico;

III - vedação a cobrança por quilômetro, tempo ou qualquer outra forma que não seja o compartilhamento dos custos de combustível e estacionamento, proporcional ao trajeto e ao número de pessoas incluindo o próprio motorista; e

IV - vedada a realização sem a presença do proprietário do veículo.

Parágrafo único. As empresas fomentadoras desta atividade não poderão cobrar percentuais sobre os valores compartilhados ou realizar cobrança por cada carona intermediada, podendo, entretanto, cobrar mensalidade ou por cadastro ${ }^{22}$.

A referida norma condicionou o UBER a uma autorização a ser expedida pelo Poder Público, da mesma forma que ocorreu em Belo Horizonte, pela Lei Municipal n. 10.900 de 08 de Janeiro de 2015. Na capital mineira, a norma é direta quanto ao aplicativo, que deve ter seu administrador e operadores credenciados junto à Empresa de Transportes e Trânsito de Belo Horizonte S/A - BHTrans.

A referida norma belo-horizontina é regulamentada pelo Decreto Municipal n. 16.195 de 07 de Janeiro de 2016, que determina a necessidade de prévia concessão, permissão, autorização ou licenciamento Municipal das atividades econômicas de transporte remunerado de passageiros:

Art. $1^{\circ}$ No âmbito do Município de Belo Horizonte, o exercício da atividade econômica de transporte remunerado de passageiros, individual ou coletivo, em veículo particular ou de aluguel, promovido por pessoa física ou jurídica, depende de prévia concessão, permissão, autorização ou licença do órgão público competente, sendo vedado o transporte clandestino ou irregular de passageiros, nos termos da Lei $\mathrm{n}^{\mathrm{o}}$ 10.309, de 21 de novembro de 2011, e deste Regulamento.

Ainda, o referido Decreto determina que é considerado transporte clandestino aquele que não possuir o aval do Município, determinando que em tal situação haverá autuação e penalização:

Art. $2^{\circ}$ - Para os fins deste Decreto considera-se:

I - transporte clandestino: o transporte municipal remunerado de passageiros, individual ou coletivo, em veículo particular ou de aluguel, promovido por pessoa

\footnotetext{
${ }^{22}$ RIO DE JANEIRO. Lei Complementar n. 159, de 29 de Setembro de 2015. Regulamenta o serviço público de transporte individual remunerado de passageiros em veículo automotor, a profissão de taxista e dá outras providências. Disponível em: $\quad<$ https://leismunicipais.com.br/a/rj/r/rio-de-janeiro/leicomplementar/2015/15/159/lei-complementar-n-159-2015-regulamenta-o-servico-publico-de-transporteindividual-remunerado-de-passageiros-em-veiculo-automotor-a-profissao-de-taxista-e-da-outras-providencias $>$ Acesso em: 30 dez. 2015.
} 
forma, a ameaça de conduta da Municipalidade, que coíba a utilização do aplicativo por meio da alegada "perseguição e punição" de motoristas que dele fazem uso, acaba por atingir direito líquido e certo das próprias impetrantes, eis que impede a livre utilização de seu produto econômico. Portanto, não estão as agravadas pleiteando direito alheio, mas atuando contra o que reputam ser ameaça de lesão a direito líquido e certo próprio. 3- A constitucionalidade da Lei Municipal n. 159/2015 ainda não foi objeto de apreciação por decisão com eficácia erga omnes nesta E. Corte, sendo, portanto, admissível, que se questione se, em concreto, o referido diploma legal deve manter a presunção de constitucionalidade de que goza somente em abstrato. Na mesma linha, é questionável a frágil construção conceitual da recorrente, com o objetivo de inferir da legislação federal uma autorização para que a Municipalidade possa perseguir e punir todo aquele que pratica atividade de transporte individual sem ser taxista. 4- Em nenhum momento está em discussão aqui a competência e legitimidade da Municipalidade de regular e fiscalizar a atividade de transporte, zelando pela sua qualidade e segurança. O ponto controverso cinge-se a avaliar se exercer essa prerrogativa abrange a possibilidade de proibir todo um setor dessa atividade econômica, isto é, se é compatível com os postulados normativos da razoabilidade e da proporcionalidade, que o Município possa, em lugar de fiscalizar a presença dos requisitos para realizar o transporte, impedir que os particulares celebrem contratos de transporte individual, com pessoas que não sejam taxistas, com autorização do Poder Público. 5- A complexidade da questão impõe a adequada instrução probatória, mas em sede de juízo de cognição sumária, não parece admissível autorizar que o Poder Público possa, no curso desse feito, ser autorizado a perseguir e punir titulares e usuários de um aplicativo que até então vinha sendo utilizado livremente. Nesse sentido, considerando que a decisão atacada não é teratológica, contrária à Lei ou à evidente prova dos autos, deve ser mantida em sua integralidade, conforme o verbete sumular $\mathrm{n}^{\circ} 58$ desta Corte. AGRAVO DE INSTRUMENTO A QUE SE NEGA PROVIMENTO.

Em outras oportunidades, o Tribunal de Justiça do Rio de Janeiro confirmou a

legalidade do UBER, reafirmando a segurança liminarmente deferida em Mandados de Segurança individuais:

Ementa: AGRAVO INOMINADO. DECISÃO MONOCRÁTICA QUE DEU PROVIMENTO AO AGRAVO DA RECORRIDA. MANDADO DE SEGURANÇA. MOTORISTA PROFISSIONAL. APLICATIVO UBER. TRANSPORTE INDIVIDUAL DE PASSAGEIROS. LIMINAR. ART. 170, IV, DA CONSTITUIÇÃO FEDERAL. LIVRE INICIATIVA. PRESENÇA DOS REQUISITOS AUTORIZADORES DA MEDIDA. DECISÃO QUE NÃO MERECE REFORMA. RECURSO QUE REPRODUZ OS ARGUMENTOS DAS RAZÕES RECURSAIS, CONTRÁRIOS AO ENTENDIMENTO JURISPRUDENCIAL DESTE TRIBUNAL. INCONFORMISMO DA PARTE, QUE PERQUIRE APENAS A APRECIAÇÃO DO RECURSO PELO ÓRGÃO COLEGIADO. MANUTENÇÃO DO DECISUM. RECURSO DESPROVIDO. ELTON MARTINEZ CARVALHO LEME - DÉCIMA SÉTIMA CÂMARA CÍVEL. ACÓRDÂO 0048007-96.2015.8.19.0000 -

AGRAVO DE INSTRUMENTO

Data de julgamento: 09/03/2016. Data de publicação: 14/03/2016.

Ementa: Agravo de Instrumento em Mandado de Segurança. Administrativo e Constitucional. Insurgência da Edilidade contra Decisão de concessão liminar da Ordem para que a Autoridade Coatora se abstenha de reprimir o exercício da atividade profissional do impetrante. Transporte privado de passageiros com o auxílio do aplicativo UBER. Questões da órbita social, envolvendo inovações 


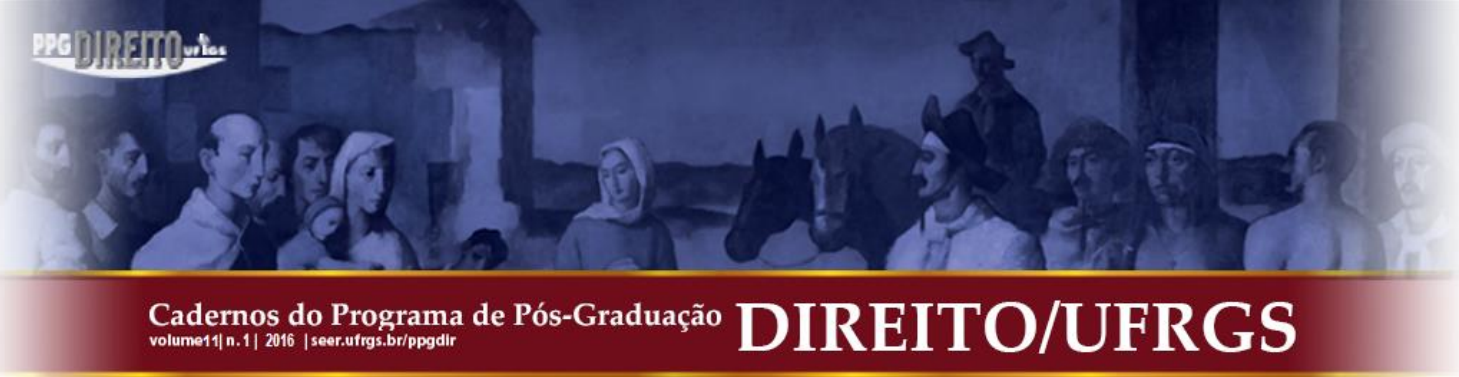

AGRAVO INTERNO. Recurso interposto com o objetivo de reformar decisão que indeferiu a antecipação dos efeitos da tutela. Inadmissibilidade. RECURSO NÃO CONHECIDO.

PETIÇÃO JUNTADA PELO AGRAVANTE. Ausência de fato superveniente. Desnecessidade de abertura de prazo para contraminuta. Impossibilidade de rediscutir os argumentos já narrados no agravo de instrumento e no agravo regimental exaustivamente. PETIÇÃO NÃO CONHECIDA.

AGRAVO DE INSTRUMENTO. MANDADO DE SEGURANÇA. IMPETRANTE MOTORISTA DA UBER. Liminar indeferida pelo MM. Juízo a quo. Não constatação, nessa estreita seara recursal, de direito líquido e certo, requisitos essenciais para a concessão do mandado de segurança. Art. $1^{\circ}$, caput, da Lei $\mathrm{n}^{\mathrm{o}}$ 12.016/2009 e art. 5º, LXIX, da Constituição Federal. Impossibilidade de se conceder proteção jurídica preventiva. Inadmissibilidade de se deferir ao impetrante uma imunização generalizada em face do poder de polícia administrativa. Incerteza conceitual e normativa que não permite ao Poder Judiciário interditar a fiscalização administrativa. Jurisprudência deste E. TJSP. RECURSO DESPROVIDO.

(Relator(a): Antonio Celso Faria; Comarca: Campinas; Órgão julgador: $8^{\text {a }}$ Câmara de Direito Público; Data do julgamento: 04/05/2016; Data de registro: 05/05/2016)

AGRAVO DE INSTRUMENTO. 1. Tutela provisional. Uber. Pretensão do Sindicato dos Taxistas Autônomos de São Paulo à limitação, em caráter liminar, do universo de prestadores cadastrados na empresa a taxistas autorizados. Inadmissibilidade. Controvérsia a respeito da natureza dos serviços prestados que há de ser dirimida após regular contraditório, por constituir questão de alta indagação. Não verificada flagrante ilegalidade ou teratologia na decisão agravada, uma vez reduzida aos limites do pedido. 2. Citação e comparecimento espontâneo. Peticionamento por advogado despido de poderes para recepção de citação. Não caracterização. Precedentes. 3. Recurso não provido.(Relator(a): Coimbra Schmidt; Comarca: São Paulo; Órgão julgador: $7^{\text {a }}$ Câmara de Direito Público; Data do julgamento: 02/05/2016; Data de registro: 02/05/2016)

Salienta-se que a decisão desfavorável ao UBER não se baseou em hipotética ilegalidade de tal serviço, mas tão somente na inexistência de direito líquido e certo do motorista em exercer tal atividade. $\mathrm{O}$ não reconhecimento de um direito não implica em declarar uma situação ilegal. A ausência de ilegalidade é reforçada pelo segundo aresto colacionado, que nega a pretensão do Sindicato dos Taxistas Autônomos de São Paulo em limitar os serviços via plataforma UBER.

Em Belo Horizonte, na $2^{\mathrm{a}}$ Vara da Fazenda Pública e Autarquias, foi impetrado o Mandado de Segurança n. 5017262-07.2016.8.13.0024, contra um eventual ato coator emanado pelas autoridades de trânsito daquela cidade com fulcro na Lei Municipal n. 10.900/2016 e no Decreto Municipal n. 16.195/2016.

Em decisão liminar, o julgador declarou que a natureza dos serviços oferecidos na plataforma UBER é privada, não se tratando de transporte público; que se trata do contrato de transporte previsto no art. 730 do Código Civil, celebrado entre particulares; e que o referido 


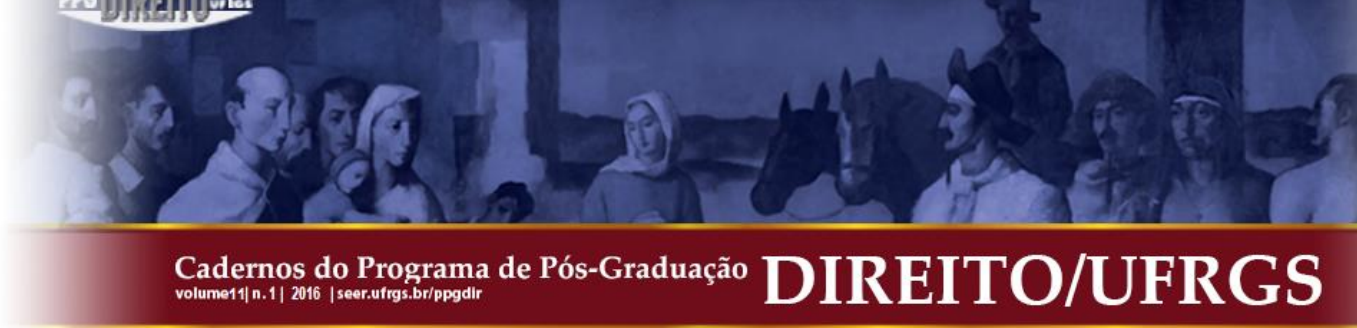

serviço não se sujeita ao licenciamento Municipal por não se tratar de transporte público, conforme trecho aqui transcrito:

Trata-se de mandado de segurança preventivo com pedido liminar impetrado por MARCUS VINICIUS REZENDE SILVA em face do CHEFE DA GUARDA MUNICIPAL DE BELO HORIZONTE, DIRETOR-PRESIDENTE DA EMPRESA DE TRANSPORTES E TRÂNSITO DE BELO HORIZONTE S.A. [BHTRANS], COMANDANTE GERAL DA POLÍCIA MILITAR DE MINAS GERAIS e do DIRETOR-GERAL DO DEPARTAMENTO DE ESTRADAS DE RODAGEM DE MINAS GERAIS [DER/MG].

Intimado para regularizar sua representação processual, o impetrante acostou substabelecimento (id 5924656).

É o relatório, em síntese. DECIDO.

Nos termos do art. 7o, inciso III, da Lei no 12.016/2009, só se autoriza a concessão liminar em mandado de segurança quando for relevante o fundamento e do ato impugnado puder resultar a ineficácia da medida, se deferida ao final.

In casu, segundo alega o impetrante, em face do que dispõem a Lei n. 10.900/2016 e o Decreto n. 16.195/2016, ambos do Município de Belo Horizonte, e o art. 231, VIII, do Código de Trânsito Brasileiro - CTB, teme ser impedido de exercer livremente sua atividade laboral, estando sujeito a "drásticas sanções" por parte das autoridades de trânsito descritas na inicial.

No presente caso, discute-se a possibilidade de intervenção estatal nos contratos de transporte privado realizados através do aplicativo UBER, ante a crescente fiscalização exercia pelas autoridades de trânsito que culminam em autuações pela prática de "transporte irregular de passageiros".

Primeiramente, deve-se destacar que a legislação invocada pelo impetrante abarca, tão somente, os serviços de transporte público sujeitos à regulamentação do respectivo órgão concedente, como é o caso dos serviços de táxi urbano, o qual se difere dos serviços prestados pelo impetrante.

Não obstante isso, considerando que o presente mandamus é preventivo, reputo justa a pretensão do impetrante que se vê ameaçado de sofrer lesão ao direito de exercer, livremente, sua atividade econômica.

Neste sentido, impõe-se esclarecer que o transporte ofertado pelo impetrante, intermediado pelo aplicativo UBER, é oferecido de forma privada, ou seja, um particular contrata, com outro particular, um serviço de transporte através do mencionado aplicativo.

Tal modalidade de contrato encontra-se expressamente prevista no Código Civil Brasileiro, conforme dispõe o artigo 730 daquele codex, in verbis: "Pelo contrato de transporte alguém se obriga, mediante retribuição, a transportar, de um lugar para outro, pessoas ou coisas".

Da mesma forma, a Lei Federal n. 12.587/2012, que instituiu as diretrizes da Política Nacional de Mobilidade Urbana, reconhece a existência de diversos modos de transporte urbano, distinguindo-os, quanto à natureza do serviço, entre público e privado (art. $3^{\circ}, \S 2^{\circ}$, III).

A referida legislação federal assim define o denominado "transporte motorizado privado: meio motorizado de transporte de passageiros utilizado para a realização de viagens individualizadas por intermédio de veículos particulares" (art. $\left.4^{\circ}, \mathrm{X}\right)$.

Evidente, portanto, que o contrato viabilizado através do aplicativo UBER tem natureza privada, motivo pelo qual não se sujeita ao credenciamento que a lei do Município de Belo Horizonte n. 10.900/2016 passará a exigir a partir de sua regulamentação.

Da mesma forma, o impetrante também não está sujeito às disposições do Decreto Municipal n. 16.195/2016, já que a concessão, permissão, autorização ou licença para exercício da atividade econômica de transporte remunerado de passageiros, 


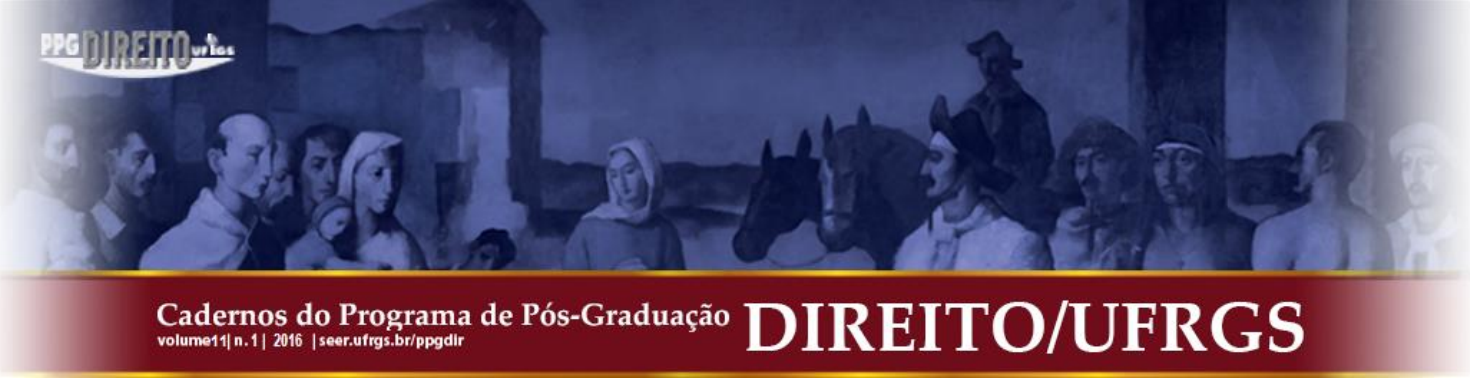

prevista em seu art. $1^{\circ}$, destina-se, exclusivamente, aos serviços de transporte público.(...).

Em outra oportunidade, em decisão interlocutória proferida no Mandado de Segurança Coletivo n. 5014923-75.2016.8.13.0024, impetrado pela Sociedade de Usuários de Informática e Telecomunicações de Minas Gerais (SUCESU-MG) em face de atos coatores das autoridades belo-horizontinas, o Judiciário mineiro, através do juiz da $1^{\text {a }}$ Vara da Fazenda Pública e Autarquias da Comarca de Belo Horizonte, novamente se manifestou no mesmo sentido (de que o serviço de transporte ofertado pelo UBER tem natureza privada), e, ainda, baseando-se na livre iniciativa, um dos fundamentos da República Federativa do Brasil, nos termos do art. $1^{\circ}$, III, da Constituição:

Trata-se de "MANDADO DE SEGURANÇA COLETIVO PREVENTIVO C/C COM PEDIDO LIMINAR" (sic) impetrado pela SOCIEDADE DOS USUÁRIOS DE INFORMÁTICA E TELECOMUNICAÇÕES DE MINAS GERAIS - SUCESU - MG em face do COMANDANTE DA GUARDA MUNICIPAL DE BELO HORIZONTE, do DIRETOR DA EMPRESA DE TRANSPORTES E TRÂNSITO DE BELO HORIZONTE S.A. - BHTRANS, do COMANDANTE DO BATALHÃO DE POLÍCIA DE TRÂNSITO DA POLÍCIA MILITAR DE MINAS GERAIS e do DIRETOR GERAL DO DEPARTAMENTO ESTADUAL DE TRÂNSITO DE MINAS GERAIS - DETRAN, com pedido de liminar para determinar que as autoridades impetradas "se abstenham de praticar atos que coíbam o uso de aplicativos baseados em dispositivos de tecnologia móvel ou quaisquer outros sistemas georreferenciados destinados à captação, disponibilização e intermediação de serviços de transporte individual de passageiros no Município".

Passo a decidir a liminar.

Os fundamentos aduzidos na inicial são relevantes ao ponto de autorizar a concessão liminar da segurança, uma vez que os valores sociais do trabalho e da livre iniciativa são fundamentos da República, à luz do artigo $1^{\circ}$ da Constituição da República Federativa do Brasil, devendo também ser sobrelevada, de plano, a diferença entre prestação de transporte público e contrato particular de transporte, espécie em que se enquadra o denominado UBER.

Preconiza o artigo $1^{\circ}$ da Constituição da República Federativa do Brasil que:

"A República Federativa do Brasil, formada pela união indissolúvel dos Estados e Municípios e do Distrito Federal, constitui-se em Estado Democrático de Direito e tem como fundamentos:

I - a soberania;

II - a cidadania;

III - a dignidade da pessoa humana;

IV - os valores sociais do trabalho e da livre iniciativa;

$V$ - o pluralismo político.

Parágrafo único. Todo o poder emana do povo, que o exerce por meio de representantes eleitos ou diretamente, nos termos desta Constituição" (sublinhei).

No mesmo sentido é o inciso XIII do artigo $5^{\circ}$ do mesmo texto constitucional:

"é livre o exercício de qualquer trabalho, oficio ou profissão, atendidas as qualificações profissionais que a lei estabelecer"

O artigo 730 do Código Civil Brasileiro, por sua vez, reza que:

"Pelo contrato de transporte alguém se obriga, mediante retribuição, a transportar, de um lugar para outro, pessoas ou coisas". 


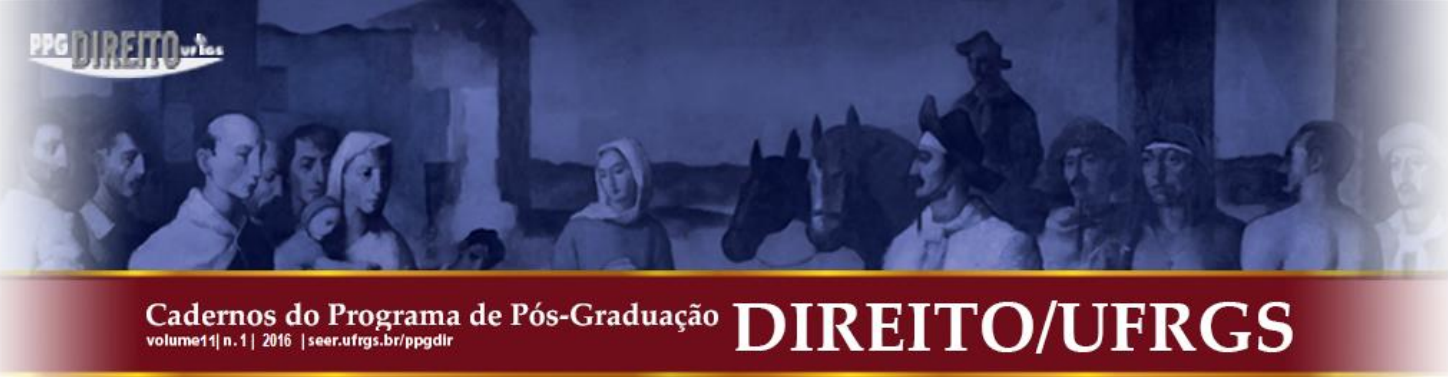

Como se vê, o serviço de transporte de pessoas oferecido através de aplicativo de dispositivo móvel (aparelhos celulares, tablets etc), como por exemplo, o UBER, insere-se na modalidade de contrato particular de transporte, não se confundindo com o serviço público de transporte prestado por taxistas, mediante permissão do poder público.

Ademais, a sentença que eventualmente reputar qualquer ato prejudicial a Sociedade autora, no particular, como, de fato, arbitrário ou ilegal, restará ineficaz.

Em outras palavras, significa dizer que, além da relevância dos fundamentos, encontra-se presente também o periculum in mora que se faz necessário para a concessão da liminar em seara de mandado de segurança, considerando sobretudo a ineficácia de decisão posterior.

Isto posto, concedo liminarmente a ordem para determinar que as autoridades impetradas e seus subordinados se abstenham de praticar atos que coíbam o uso de aplicativos baseados em dispositivos de tecnologia móvel ou quaisquer outros sistemas georreferenciados destinados à captação, disponibilização e intermediação de serviços de transporte individual de passageiros neste Município.

Notifiquem-se as autoridades apontadas como coatoras, nos termos do art. $7^{\circ}$, inciso I, da Lei n ${ }^{\circ}$ 12.016/09. Dê-se ciência ao Advogado Geral do Estado e ao Procurador Geral do Município, nos termos do artigo $7^{\circ}$, inciso II, da Lei 12.016 , bem como ao Ministério Público, nos termos do artigo 12 da mesma lei.

Também em Belo Horizonte, pelo Juízo da $1^{\text {a }}$ Vara de Feitos da Fazenda Pública Municipal de Belo Horizonte, verifica-se sentença desfavorável ao UBER, com o trecho aqui transcrito:

(...) Na hipótese dos autos, embora o impetrante tenha demonstrado que exerce atividade profissional usando o aplicativo UBER, não é possível aferir o necessário direito líquido e certo para os fins pretendidos no presente mandamus.

Afirmou o requerente que a demanda foi impetrada "contra a Lei 10.900/2016", de 08/01/2016, sancionada pelo Prefeito de Belo Horizonte.

Verifica-se que a referida lei diz respeito ao "credenciamento de pessoas jurídicas que operam e/ou administram aplicativos destinados à captação, disponibilização e intermediação de serviços de transporte individual remunerado de passageiros no Município de Belo Horizonte; sobre dispositivos de segurança e controle da atividade; sobre penalidades e dá outras providências".

A toda evidência, não se vislumbra direito líquido e certo com base nas alegações do impetrante, mera pessoa física.

Portanto, impõe-se reconhecer que não é caso de mandado de segurança, com aplicação do art. 10 da Lei 12.016/09, que traz em seu bojo uma situação de indeferimento liminar da pretensão pelo motivo acima e pela ausência de requisitos legal.

Diante do exposto, verificando de plano a inexistência de direito líquido e certo amparado por mandado de segurança, com fundamento no art. 10 da Lei ${ }^{\circ}$ 12.016/09, c/c o art. 295, V, do CPC, INDEFIRO A INICIAL do presente mandamus, determinando o arquivamento dos autos, com baixa.

Verifica-se, que assim como no julgado de São Paulo, o indeferimento não se deu por ilegalidade dos serviços de transporte prestados pelo aplicativo UBER, mas apenas por não se vislumbrar o direito líquido e certo. No caso de Belo Horizonte, ainda, conforme já citado no 


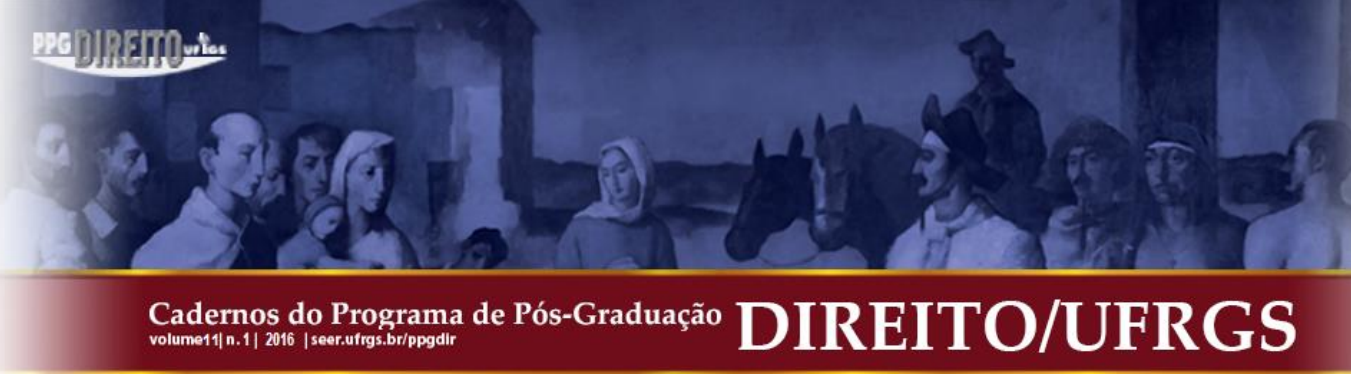

tópico anterior, destaca-se que a Lei Municipal determina a necessidade do credenciamento das empresas, razão pela qual não se verificou o direito líquido e certo do motorista.

Por fim, ressalta-se que todas essas decisões proferidas em Belo Horizonte certamente serão reanalisadas, em sede de recurso, pelo Tribunal de Justiça de Minas Gerais.

\section{CONCLUSÃO}

A introdução dos serviços prestados por aplicativos como Uber têm promovido uma espécie de reforma cultural. Por anos, quedou-se imprescindível a aquisição de um carro próprio para se obter conforto e comodidade no transporte pelas grandes cidades.

No entanto, com o advento do modelo da economia compartilhada (sharing economy), emergem novos modelos bem sucedidos, principalmente, por serem de boa qualidade, preço moderado e de patente segurança.

Nesse contexto, surgiu o sistema UBER, o qual permite que pessoas contratem motoristas particulares, por meio de um aplicativo. A referida ferramenta inovou os transportes das grandes metrópoles e passou a ser utilizada em larga escala. Para se ter ideia da expansão dos serviços UBER no mundo, Tatiana Nascimento ${ }^{23}$ aduz que, atualmente, a cidade de Nova York possui mais carros na plataforma UBER do que taxis (15 mil carros UBER contra 13,5 mil taxis).

Todavia, o sucesso do aplicativo começou a causar transtornos para aqueles que atuam com o serviço de utilidade pública de transporte individual - os taxistas, que passaram apontar a ilegalidade da ferramenta.

O presente estudo diferenciou os serviços prestados pelos taxistas e pelo UBER, demonstrou a possibilidade de existência concomitante das duas vertentes.

Restou demonstrado por meio deste estudo que o transporte individual de passageiros se divide em duas modalidades: a "pública", um serviço de utilidade pública, prestada de modo privativo pelos táxis, sujeitando-se a regulação estatal; e, a "privada", autorizada pelos princípios da livre iniciativa (art. $1^{\circ}$, IV e 170, caput, CR/88), e da livre concorrência (art. $170, \mathrm{IV}, \mathrm{CR} / 88)$.

\footnotetext{
${ }^{23}$ NASCIMENTO, Tatiana. Entenda a briga entre taxistas e motoristas do aplicativo UBER. Fantástico. Rede Globo de Televisão. Exibido em 26 de Julho de 2015. Disponível em $<$ http://g1.globo.com/fantastico/noticia/2015/07/entenda-briga-entre-taxistas-e-motoristas-do-aplicativouber.html>. Acesso em: 30 dez. 2015.
} 


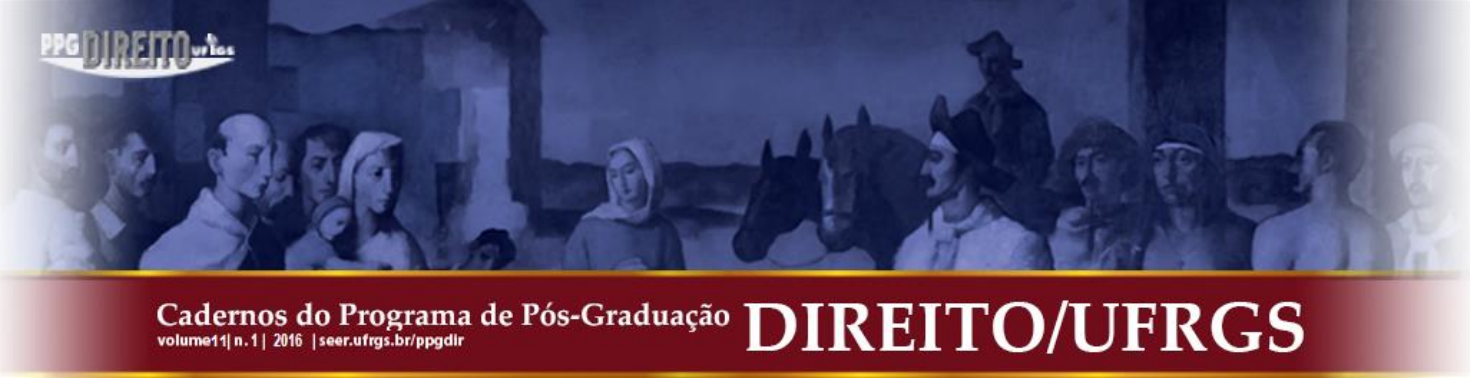

Fazendo uma análise jurídica da questão dos serviços oferecidos no UBER, constata-se que a prestação de serviços do UBER enquadra-se, perfeitamente, no contrato de transporte de pessoas, previsto no Código Civil Brasileiro, pela qual uma das partes, o transportador, ou condutor, se obriga a deslocar de um lugar para outro, a outra parte (passageiro).

O contrato de transporte de pessoas mostra-se lícito, sobretudo, porque se trata de um negócio firmado entre particulares, no qual impera a autonomia privada do motorista do UBER, que tem o direito de aceitar e firmar o contrato com o consumidor de acordo com sua conveniência.

Conclui-se, pois, que a instituição de reservas e privilégios desejados pelos taxistas viola, de forma latente, os interesses dos consumidores e de toda a sociedade.

O tema é recente e carece de amadurecimento normativo e jurisprudencial. Alguns Municípios passaram a regulamentar o serviço (restringindo-o ou vedando-o), mas as referidas normas sequer foram regulamentadas. A jurisprudência aponta pela legalidade do assunto, e as decisões desfavoráveis não reconhecem ou declaração a ilicitude dos serviços, apenas se limitam a declarar a ausência de direito líquido e certo do motorista para exercer tal atividade.

Por fim, em uma análise pela ciência jurídica e pelas normas envolvidas, pode-se afirmar desde já que os serviços de transporte privado de pessoas, disponibilizados pelo aplicativo UBER, são lícitos, legais e não se configuram como um serviço público de transporte de pessoas, que seria de competência municipal.

\section{REFERÊNCIAS}

ABREU FILHO, José. O negócio jurídico e sua teoria geral. 5. ed. São Paulo: Saraiva, 2003.

BELO HORIZONTE. Lei 10.900, de 08 de Janeiro de 2016. Dispõe sobre o credenciamento de pessoas jurídicas que operam e/ou administram aplicativos destinados à captação, disponibilização e intermediação de serviços de transporte individual remunerado de passageiros no Município de Belo Horizonte; sobre dispositivos de segurança e controle da atividade; sobre penalidades e dá outras providências.. Disponível em: $<$ http://portal6.pbh.gov.br/dom/iniciaEdicao.do?method=DetalheArtigo\&pk=1156232> Acesso em: 10 jan. 2016. 
. Decreto 16.195, de 07 de Janeiro de 2016. Regulamenta a Lei n. 10.900, de 08 de Janeiro de 2016.2 Disponível em: $<$ http://portal6.pbh.gov.br/dom/iniciaEdicao.do?method=DetalheArtigo\&pk=1156151> Acesso em: 10 jan. 2016.

BRASIL. Constituição da República Federativa do Brasil de 1988. Disponível em: $<$ http://www.planalto.gov.br/ccivil_03/Constituicao/Constituicao.htm> Acesso em: $30 \mathrm{dez}$. 2015.

- Lei 10.406, de 10 de Janeiro de 2002. Código Civil. Disponível em:

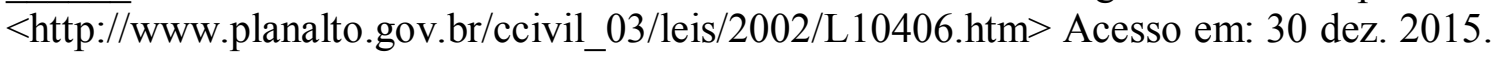

. Lei 12.468, de 26 de Janeiro de 2011. Regulamenta a Profissão de taxista e dá outras providências. Disponível em: <http://www.planalto.gov.br/ccivil_03/_Ato20112014/2011/Lei/L12468.htm> Acesso em: 30 dez. 2015.

Lei 12.587, de 3 de Janeiro de 2012. Institui a política nacional de mobilidade urbana. Disponível em: <http://www.planalto.gov.br/ccivil_03/_ato20112014/2012/lei/112587.htm>. Acesso em: 30 dez. 2015.

CARDOSO, Ana Luíza. UBER, o aplicativo que enfurece os motoristas: o serviço para chamar motoristas particulares no mundo chega ao Brasil. Revista Época. Editora Globo. Publicado em 22 de Julho de 2014. Disponível em <http://epoca.globo.com/vida/vidautil/tecnologia/noticia/2014/07/buber-o-aplicativob-que-enfurece-os-taxistas.htmlac $>$. Acesso em: 30 dez. 2015.

CORRÊA, Alessandra. UBER: Conheça as polêmicas globais e onde já foi regulamentado. $B B C$ Brasil. Publicado em 12 de Agosto de 2015. Disponível em $<$ http://www.bbc.com/portuguese/noticias/2015/08/150812_uber_regulamentacao_pai_ac $>$. Acesso em: 30 dez. 2015.

DINIZ, Maria Helena. Novo Código Civil Comentado. São Paulo: Saraiva, 2002.

ESTEVES, Luiz Alberto. O Mercado de Transporte Individual de Passageiros: Regulação, Externalidades e Equilibrio Urbano. Departamento de Estudos Econômicos (DEE) do Conselho Administrativo de Defesa Econômica (CADE). Disponível em $<$ http://www.cade.gov.br/upload/O\%20Mercado\%20de\%20Transporte\%20Individual\%20de $\% 20$ Passageiros.pdf $>$. Acesso em: 30 dez. 2015. 


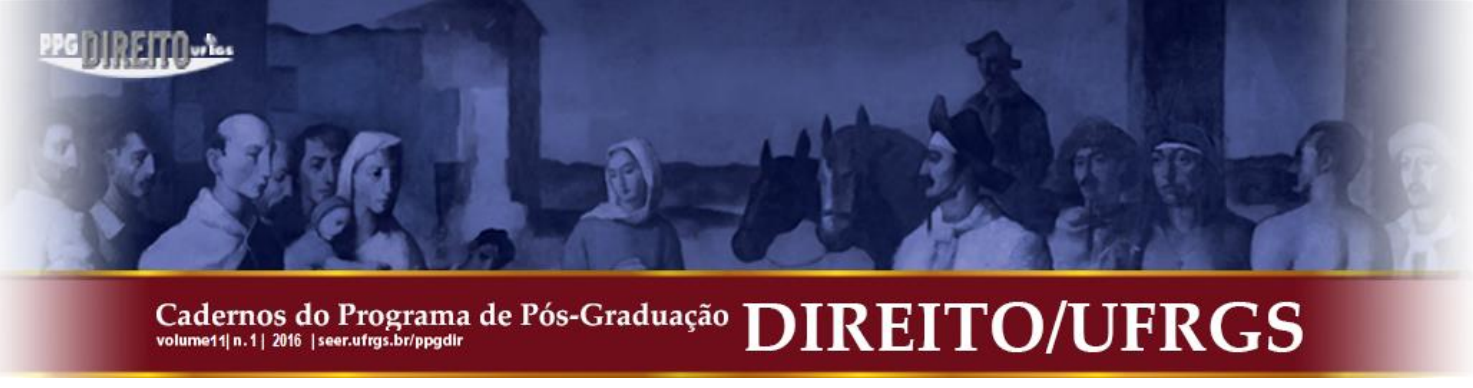

FORGIONI, Paula. Princípios constitucionais econômicos e princípios constitucionais sociais. A formatação jurídica do mercado brasileiro. Revista do Advogado. n. 117, 2012.

GOMES, Orlando. Contratos. Rio de Janeiro: Forense, 2001.

JORDÃO, Eduardo Ferreira. Restrições Regulatórias à Concorrência. Belo Horizonte: Ed. Fórum, 2009.

GRAU, Eros Roberto. A Ordem Econômica na Constituição de 1988 (interpretação e crítica).

MELlO, Celso Antônio Bandeira de. Serviços Públicos e Serviço de Utilidade Pública Caracterização dos Serviços de Táxi - Ausência de Precariedade na Titulação para prestá-los - Desvio de Poder Legislativo. Pareceres de Direito Administrativo. São Paulo: Malheiro, 2011.

MINAS GERAIS. $1^{\text {a }}$ Vara dos Feitos da Fazenda Pública Municipal de Belo Horizonte do Tribunal de Justiça. Sentença no Processo n. 5009081-17.2016.8.13.0024. Impetrante Gustavo Machado Pires, impetrado Diretor-Presidente da BHTRANS. Juiz Luis Maurício Leitão Linhares . Julgado e publicado em 29 de Janeiro de 2016. Disponível em < http://pje.tjmg.jus.br/pje/ConsultaPublica/DetalheProcessoConsultaPublica/documentoSemLo ginHTML.seam?ca=01 e6a9a6910d1c941ca8fa8cc3f9593e97a3daa149729227fla1 b08bef506a 2f1973dc99bf446d2c4227e94995eb5adbcdf583e32930579a>. Acesso em: 10 maio 2016.

. $1^{\text {a }}$ Vara da Fazenda Pública e Autarquias da Comarca de Belo Horizonte do Tribunal de Justiça. Decisão Interlocutória no Processo n. 5014923-75.2016.8.13.0024. Impetrante SUCESU-MG Sociedade de Usuários de Informática e Telecomunicações de Minas Gerais, impetrado Diretor-Presidente da BHTRANS e outros. Juiz Michel Curi e Silva . Julgado e publicado em 10 de Março de 2016. Disponível em < http://pje.tjmg.jus.br/pje/ConsultaPublica/DetalheProcessoConsultaPublica/documentoSemLo ginHTML.seam?ca=2a686b2259eaf2481 ca8fa8cc3f9593e97a3daa149729227fla1 b08bef506a 2f1973dc99bf446d2c4227e94995eb5adbcdf583e32930579a>. Acesso em: 10 maio 2016.

. $2^{\text {a }}$ Vara da Fazenda Pública e Autarquias da Comarca de Belo Horizonte do Tribunal de Justiça. Decisão Interlocutória no Processo n. 5017262-07.2016.8.13.0024. Impetrante Marcus Vinicius Rezende Silva, impetrado Diretor-Presidente da BHTRANS e outros. Juiz Luis Fernando de Oliveira Benfatt . Julgado e publicado em 15 de Fevereiro de 2016. Disponível em http://pje.tjmg.jus.br/pje/ConsultaPublica/DetalheProcessoConsultaPublica/documentoSemLo 


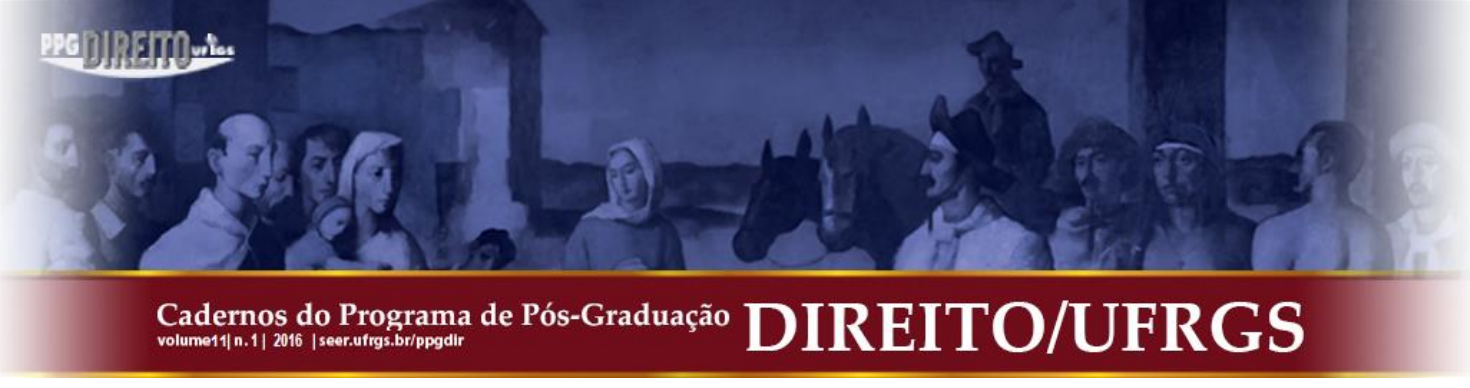

Lei 16.279, de 08 de Outubro de 2015. Dispõe sobre a proibição do uso de carros particulares cadastrados em aplicativos para o transporte remunerado individual de pessoas no Município de São Paulo e dá outras providências. Disponível em: < https://leismunicipais.com.br/a/sp/s/sao-paulo/lei-ordinaria/2015/1627/16279/lei-ordinaria-n16279-2015-dispoe-sobre-a-proibicao-do-uso-de-carros-particulares-cadastrados-emaplicativos-para-o-transporte-remunerado-individual-de-pessoas-no-municipio-de-sao-pauloe-da-outras-providencias> Acesso em: 30 dez. 2015.

Tribunal de Justiça. Acórdão do Agravo de Instrumento n. 006183732.2015.8.19.0000. Agravante Sindicato dos Taxistas Autônomos de Guarulhos, agravado Uber do Brasil Tecnologia Ltda. e outros. Desembargadora Relatora Paula Galizia. Julgado em 30 de Novembro de 2015, publicado em 02 de Dezembro de 2015. Disponível em < https://esaj.tjsp.jus.br/cjsg/getArquivo.do?cdAcordao=9040486\&cdForo=0\&vlCaptcha $=$ yhmy v>. Acesso em: 10 jan. 2016.

Tribunal de Justiça. Acórdão do Agravo de Instrumento n. 206052385.2016.8.26.0000. Agravante Benedito Edson do Nascimento, agravado Presidente da Empresa Municipal de Desenvolvimento de Campinas S/A. e outros. Desembargador Relator Antônio Celso Faria. Julgado em 04 de Maio de 2016 e publicado em 05 de Maio de 2016. Disponível em

https://esaj.tjsp.jus.br/cjsg/getArquivo.do?cdAcordao=9410451\&cdForo=0\&vlCaptcha=zkzxr >. Acesso em: 10 maio 2016.

Tribunal de Justiça. Acórdão do Agravo de Instrumento n. 212866056.2015.8.26.0000. Agravante Sindicato das Empresas de Táxi e Locação de Táxi do Estado de São Paulo e outros, agravado Uber do Brasil Tecnologia Ltda. e outros. Desembargadora Relatora Silvia Rocha. Julgado e publicado em 15 de Julho de 2015. Disponível em < https://esaj.tjsp.jus.br/cjsg/getArquivo.do?cdAcordao $=8623637 \& \mathrm{cdForo}=0>$. Acesso em: 10 jan. 2016.

- Tribunal de Justiça. Acórdão do Agravo de Instrumento n. 219977018.2015.8.26.0000. Agravante Sindicato das Empresas de Táxi e Locação de Táxi do Estado de São Paulo e outros, agravado Uber do Brasil Tecnologia Ltda. e outros. Desembargador Relator Coimbra Schmidt. Julgado e publicado em 02 de Maio de 2016. Disponível em < https://esaj.tjsp.jus.br/cjsg/getArquivo.do?cdAcordao=9395426\&cdForo=0 $>$. Acesso em: 10 jan. 2016.

Submissão: 29/01/2016

Aceito para Publicação: 31/05/2016 


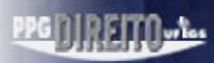

Cadernos do Programa de Pós-Graduação volume11|n.1| 2016 | seer.ufrgs.br/ppgdil

DIREITO/UFRGS 